\title{
Silk Fibroin and its Application in Tissue Engineering
}

\author{
Ke Wang ${ }^{1,2}$, Qian Ma1, Xiao Qin¹,2 and Shu Dong Wang1* \\ ${ }^{1}$ Jiangsu Research and Development Center of the Ecological Textile Engineering and Technology, School of Textile and Clothing, Yancheng Polytechnic \\ College, China
}

${ }^{2}$ Industrial Research Institute of Nonwovens \& Technical Textiles, The State Key Laboratory of New Fiber Materials and Modern Textile, Qingdao University, China

Submission: November 01, 2018; Published: November 19, 2018

*Corresponding author: Shu-Dong Wang,Jiangsu Research and Development Center of the Ecological Textile Engineering and Technology, School of Textile and Clothing, Yancheng Polytechnic College, Yancheng, 224005, PR China

\section{Abstract}

Due to the special luster, good air permeability and moisture permeability, comfortable wearing, delicate and smooth feel, silk fiber is wildly used in textiles. Recently, with the careful study of the composition, microstructure and physicochemical properties of silk, the application of silk has gradually extended to food, biomedicine, industrial raw materials, environmental protection and other fields. This paper gives one short introduction of silk's application in tissue engineering.

Keywords: Silk worm; Silk fiber; Silk fibroin; Tissue engineering

\section{Introduction of Silk Fibroin}

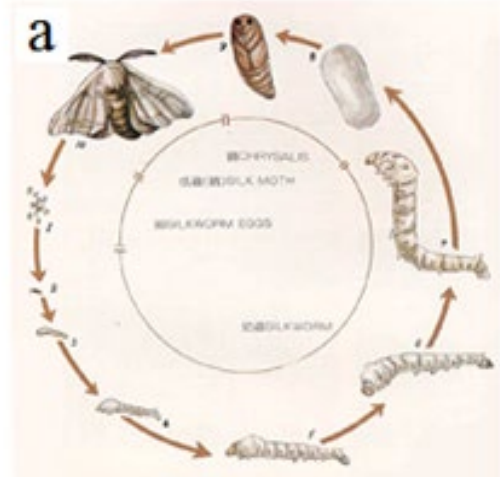

The life circle of silkworm

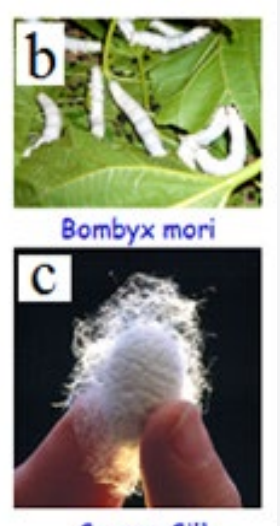

Cocoon Silk
Figure 1: (a) life cycle of silkworm (b) Bombyx mori silkworms (c) silkworm cocoon [1-3].

Silk industry is an important support of national economy in China. Recently, silk is affected by reduction of farmland, shortage of labor, and low added value of the products. Developing the versatile silk industry and increasing the added value of silk are the ways to achieve the transformation, upgrading and sustainable development of silk. Figure 1 shows the life cycle of the silkworm. It can be seen from the diagram that after hatching from eggs, silkworms begin to spin and cocoon after five stages of growth and maturity, and then become moths after cocooning. At the end of the fifth instar silkworm, a large amount of raw silk is expelled from its pair of silk glands (Figure $2(\mathrm{~A})$ ) and gradually forms a cocoon. Raw silk is composed of two parallel sericincoated silk fibers [1-7] (Figure 2 (B)). After silk degumming, the obtained silk fibroin fiber has a bright pearl-like luster and a soft feel, which is very popular in the textile industry. In addition, silk fibroin fibers are widely used in many fields because of their unique mechanical properties and flexibility, biocompatibility, biodegradability and thermal stability [8].

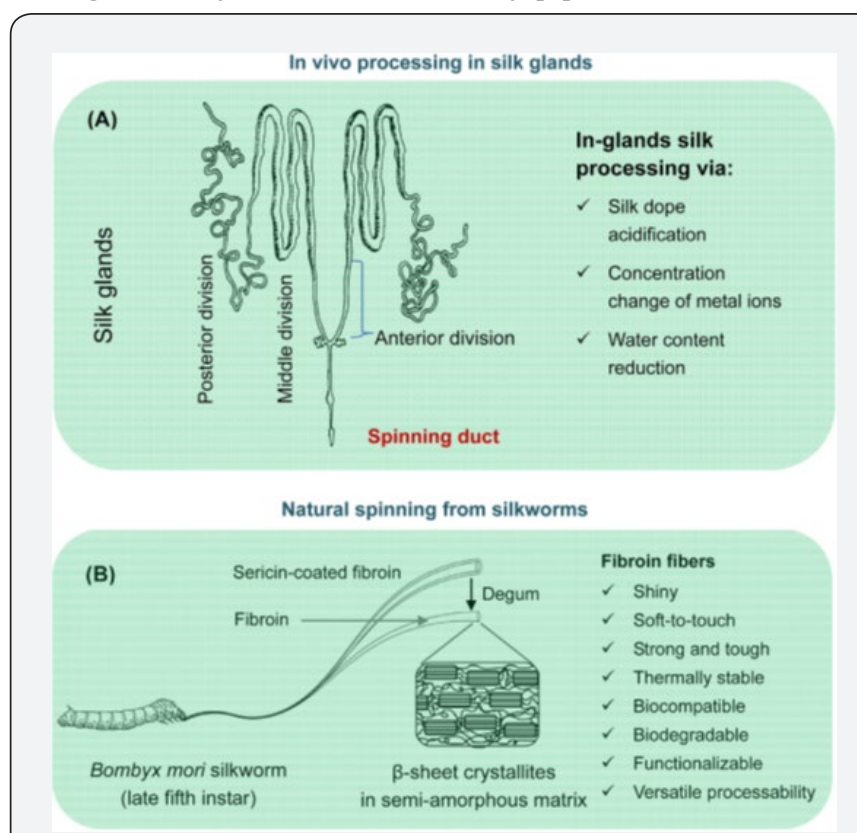

Figure 2: (A)In vivo processing in silk glands; (B) Natural spinning by silkworms to produce fibroin fibers with unique features [7].

\section{Silk Fibroin's Application in Tissue Engineering}

Silk fibroin fibers can be prepared into conventional textile products such as woven, knitted and non-woven fabrics as shown 


\section{Current Trends in Fashion Technology \& Textile Engineering}

in (Figure 3 (a)\&(b)), and regenerated silk fibroin solutions (Figure 3 (c)) can be obtained by degumming and dissolving the silk fibers. By various preparation methods, various kinds of silk fibroin materials with different morphologies and structures can be obtained (Figure 3(d)), such as porous scaffolds, gels, films, nanofibers, microspheres, microneedles and other silk fibroin materials [9-15]. Based on the excellent biocompatibility of the above-mentioned silk fibroin and their various structural forms, silk fibroin is widely used in biomedical fields as shown in (Figure 4), such as vascular scaffolds [16], nerve regeneration [17], bone repair [18], drug release [19], heart valve [20] and skin regeneration [21]. Due to its unique mechanical flexibility, optical properties, biocompatibility, biodegradability and other characteristics, researchers are exploring the possibility of silk fibroin as a flexible electronic for biomedical application.

\section{a}

Bombyx mori silkworm and cocoon
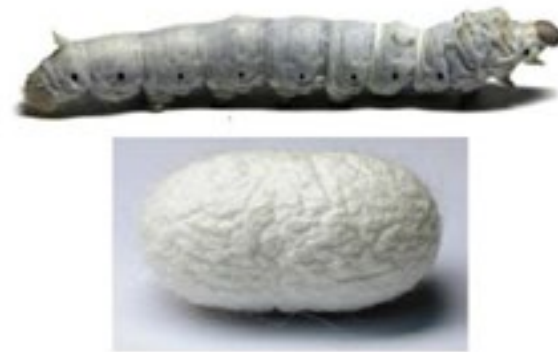

b

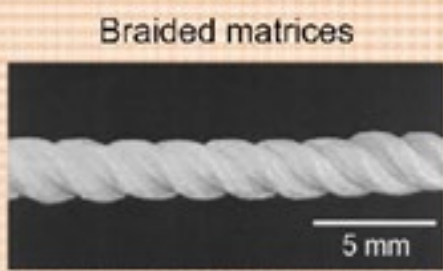

Knitted matrices

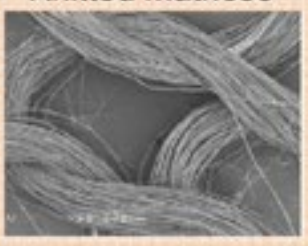

Non-woven matrices

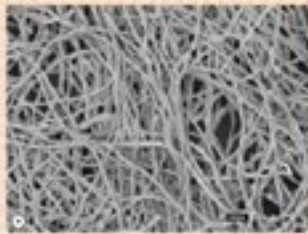

d Sponges
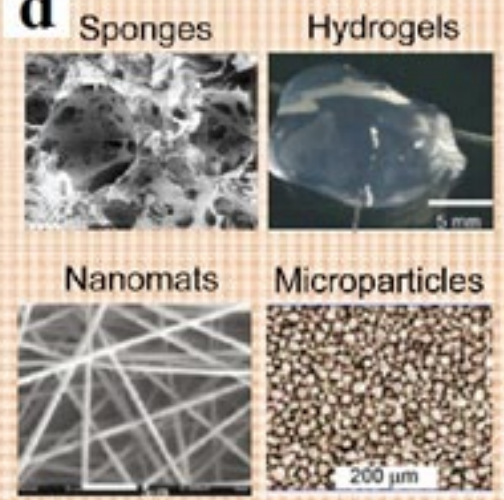

Microparticles

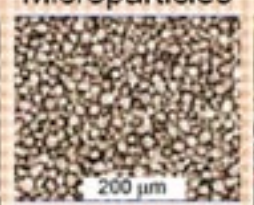

Microneedles

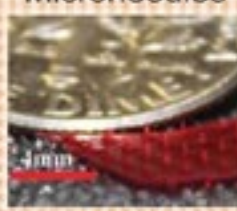

\section{Raw silk}

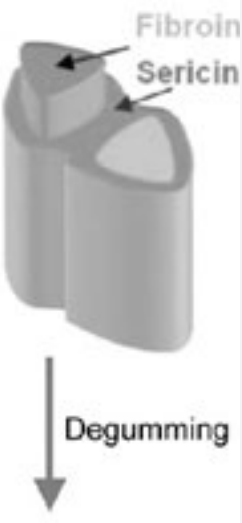

Fibroin
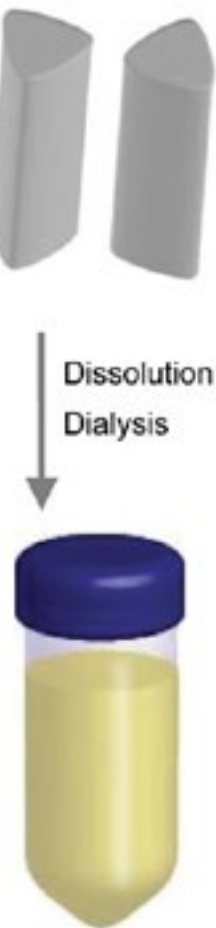

Regenerated

fibroin solution

Figure 3: Bombyx mori silkworm silk in various morphologies:

(a) Mature silkworm and produced cocoon

(b) Silk braided, knitted, and nonwoven matrices

(c) Preparation of the regenerated silk fibroin solution

(d) Silk sponges, hydrogels, films, nanofibrous mats, microparticles, and microneedles constructed from the regenerated fibroin solution [12]. 

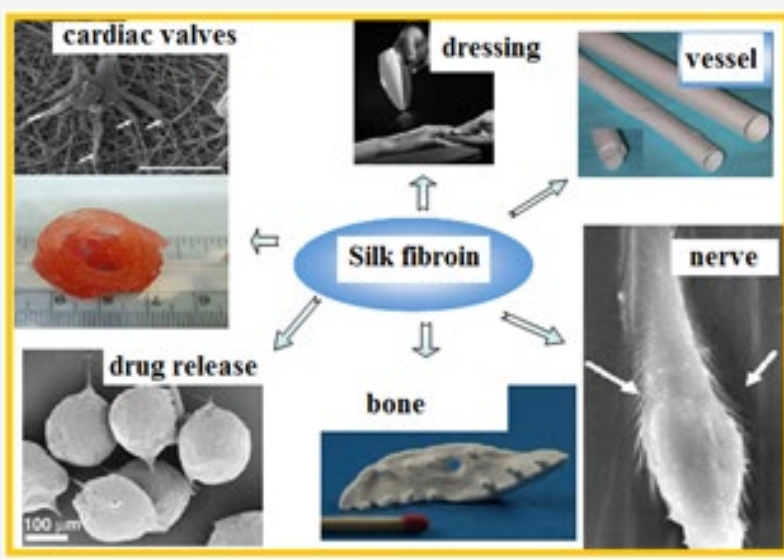

Figure 4: Silk fibroin based biomedical materials [16-21].

\section{Acknowledgement}

This research is supported by the High Education Science Foundation of Jiangsu Province under Grants 16KJB540005 and 18KJB540005. The authors acknowledge the financial from Qinglan Project of the Jiangsu Higher Education Institutions of China and the Top-notch Academic Programs Project of Jiangsu Higher Education Institutions (PPZY2015C254). The authors are grateful for Advanced Study and Train and Practice for Young Teachers of Vocational College of Jiangsu Province, China (2018QYSJ131 and 2018TDFY009).

\section{References}

1. Altman GH, Diaz F, Jakuba C, Calabro T, Horan RL, et al. (2003) Silkbased biomaterials. Biomaterials 24(3): 401-416.

2. Zhou P, Xie X, Knight DP, Zong XH, Deng F, et al. (2004) Effects of pH and calcium ions on the conformational transitions in silk fibroinusing 2D Raman correlation spectroscopy and13C solid-state NMR. Biochemistry 43(35): 11302-11311.

3. Jin HJ, Kaplan DL (2003) Mechanism of silk processing in insects and spiders. Nature 424(6952): 1057-1061.

4. Vollrath F, Porter D (2009) Silks as ancient models for modern polymers. Polymer 50(24): 5623-5632.

5. Zhou CZ, Confalonieri F, Jacquet M, Perasso R, Li ZG, et al. (2001) Silk fibroin: structural implications of a remarkable amino acidsequence. Protein Struct Funct Genet 44: 119-122.

6. Foo CWP, Bini E, Hensman J, Knight DP, Lewis RV, et al. (2006) Role of $\mathrm{pH}$ and charge on silk protein assembly in insects and spiders. Applied Physics A 82(2): 223-233.
7. Willcox PJ, Gido SP, Muller W, Kaplan DL (1996) Evidence of a cholesteric liquid crystalline phase in natural silk spinning processes. Macromolecules 29(15): 5106-5110.

8. Banani K, Kundu SC (2010) Osteogenesis of human stem cells in silk biomaterial for regenerative therapy. Progress in Polymer Science 35(9): 1116-1127.

9. Wang SD, Zhang YZ, Wang HW, Dong ZH (2011) Preparation, characterization and biocompatibility of electrospinning heparinmodified silk fibroin nanofibers. Int J Biol Macromol 48(2): 345-353.

10. Ma Y, Feng Q Bourrat X (2013) A novel growth process of calcium carbonate crystals in silk fibroin hydrogel system. Mater Sci Eng C Mater Biol Appl 33(4): 2413-2420.

11. Wen X, Peng X, Fu H, Dong Y, Han K, et al. (2011) Preparation and in vitro evaluation of silk fibroin microspheres produced by a novel ultrafine particle processing system. Int J Pharm 416(1): 195-201.

12. Vepari C, Kaplan DL (2007) Silk as a biomaterial. Prog Polym Sci 32: 991-1007.

13. Tsioris K, Raja WK, Pritchard EM, Panilaitis B, Kaplan DL, et al. (2012) Fabrication of silk microneedles for controlled-release drug delivery. Adv Funct Mater 22: 330-335.

14. Liu H, Fan H, Wang Y, Toh SL, Goh JC (2008) The interaction between acombined knitted silk scaffold and microporous silk sponge with human mesenchymal stem cells for ligament tissue engineering. Biomaterials 29 (6): 662-674.

15. Rockwood DN, Preda RC, Yücel T, Wang X, Lovett ML, et al. (2011) Materials fabrication from Bombyx mori silk fibroin. Nat Protoc 6: $1612-1631$.

16. Wang SD, Zhang YZ, Wang HW, Yin GB, Dong ZH (2009) Fabrication and properties of the electrospun polylactide/silk fibroin-gelatin composite tubular scaffold. Biomacromolecules 10(8): 2240-2244.

17. Das S, Sharma M, Saharia D, Sarma KK, Sarma MG, et al. (2015) In vivo studies of silk-based gold Nano-composite conduits for functional peripheral nerve regeneration. Biomaterials 62: 66-75.

18. Yang Y, Wang H, Yan FY, Qi Y, Lai YK, et al. (2015) Bioinspired porous octa calcium phosphate/silk fibroin composite coating materials prepared by electrochemical deposition. ACS Appl Mater Interfaces 7(10): 5634-5642.

19. Xie MB, Li Y, Zhao Z, Chen AZ, Li JS, et al. (2016) Development of silk fibroin-derived nanofibrous drug delivery system in supercritical $\mathrm{CO} 2$. Materials Letters 167: 175-178.

20. Jana S, Tefft BJ, Spoon DB, Simari RD (2014) Scaffolds for tissue engineering of cardiac valves. Acta Biomater 10(4): 2877-2893.

21. Çalamak S, Erdoğdu C, Özalp M, Ulubayram K (2014) Silk fibroin based antibacterial bio nanotextiles as wound dressing materials. Mater Sci Eng C 43: 11-20.

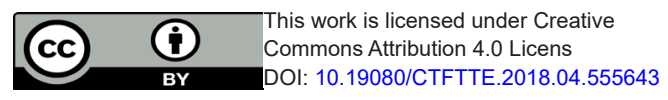

\begin{tabular}{|l|}
\hline \multicolumn{1}{|c|}{ Your next submission with Juniper Publishers } \\
will reach you the below assets \\
- Quality Editorial service \\
- Swift Peer Review \\
- Reprints availability \\
- E-prints Service \\
- Manuscript Podcast for convenient understanding \\
- Global attainment for your research \\
- Manuscript accessibility in different formats \\
( Pdf, E-pub, Full Text, Audio) \\
- Unceasing customer service \\
Track the below URL for one-step submission \\
https://juniperpublishers.com/online-submission.php \\
\hline
\end{tabular}

